\title{
A Piscirickettsia salmonis-like bacterium associated with mortality of white seabass Atractoscion nobilis
}

\author{
Martin F. Chen ${ }^{1}$, Susan Yun ${ }^{2}$, Gary D. Marty ${ }^{3}$, Terry S. McDowell ${ }^{2}$, Marcia L. House ${ }^{4}$ \\ Jaye A. Appersen ${ }^{1}$, Tim A. Guenther ${ }^{1}$, Kristen D. Arkush ${ }^{2,5}$, Ronald P. Hedrick ${ }^{2, *}$ \\ ${ }^{1}$ California Department of Fish and Game, 4478 Arbor Cove Circle, Oceanside, California 92054, USA \\ ${ }^{2}$ Department of Medicine and Epidemiology and ${ }^{3}$ Department of Anatomy, Physiology, and Cell Biology, School of \\ Veterinary Medicine, University of California, One Shields Avenue, Davis, California 95616, USA \\ ${ }^{4}$ Western Fisheries Research Center, United States Geological Survey, 6505 65th St., Seattle, Washington 98115, USA \\ ${ }^{5}$ Bodega Marine Laboratory, PO Box 247, Bodega Bay, California 94923, USA
}

\begin{abstract}
Mortality among hatchery-reared juvenile white seabass Atractoscion nobilis in southern California, USA, was associated with infections by a Piscirickettsia salmonis-like organism (WSPSLO). Infected fish had no consistent external signs other than pale gills, lethargy and impaired swimming behavior. Internally, the kidney and spleen were enlarged, and some fish had livers with multiple pale foci. Smears from infected kidney, liver, and spleen stained with Wright-Giemsa had intracytoplasmic coccoid organisms, often in pairs, that ranged in size from 0.5 to $1.0 \mu \mathrm{m}$. Microscopic lesions included multifocal hepatic, renal, and splenic necrosis, and intralesional macrophages often contained the WSPSLO. The bacterium was isolated from infected fish on cell lines of salmonid (CHSE214) and white seabass (WSBK) origin. The WSPSLO induced plaque formation and destroyed the cell monolayers within 10 to $14 \mathrm{~d}$ incubation at temperatures of 15 and $20^{\circ} \mathrm{C}$. The bacterium retained infectivity for cell lines up to $14 \mathrm{~d}$ at 4 and $13^{\circ} \mathrm{C}$, up to $7 \mathrm{~d}$ at $20^{\circ} \mathrm{C}$, but it was inactivated at 37 and $56^{\circ} \mathrm{C}$ within 24 and $1 \mathrm{~h}$, respectively. Freezing at $-20^{\circ} \mathrm{C}$ reduced infectivity by 100 -fold. Dehydration and resuspension in distilled water completely inactivated the bacterium. In contrast, the WSPSLO retained nearly all of its infectivity for CHSE-214 cells following a $72 \mathrm{~h}$ period in seawater at $20^{\circ} \mathrm{C}$. Polyclonal rabbit antibodies made to the WSPSLO reacted specifically in indirect fluorescent antibody tests (IFAT) with the bacterium in cell cultures and smears from infected fish tissues. Tissue smears from infected salmon or CHSE-214 cells with P. salmonis reacted weakly with the antiWSPSLO serum. Conversely, polyclonal anti- $P$. salmonis serum produced a weakly positive reaction with the WSPSLO from infected CHSE-214 cells. The WSPSLO as propagated in CHSE-214 cells was highly virulent for juvenile coho salmon Oncorhynchus kisutch, inducing $80 \%$ mortality within $10 \mathrm{~d}$ of intraperitoneal injection of $10^{2.5} 50 \%$ tissue culture infectious doses per fish. We conclude that the bacterium from white seabass possesses antigenic differences from $P$. salmonis yet possesses virulence for salmon equal to known strains of $P$. salmonis.
\end{abstract}

KEY WORDS: Rickettsia-like $\cdot$ Seabass $\cdot$ Piscirickettsia salmonis

Resale or republication not permitted without written consent of the publisher

\section{INTRODUCTION}

The rickettisia-like bacteria are an emerging group of pathogens among fin-fish (Fryer \& Lannan 1996,

*Corresponding author. E-mail: rphedrick@ucdavis.edu
Fryer \& Mauel 1997). The most prominent member of this group is Piscirickettsia salmonis (Fryer et al. 1992), the agent first recognized as a cause of serious mortality among Pacific salmon raised in net pens in Chile (Bravo \& Campos 1989, Branson \& Nieto-Diaz-Munoz 1991, Cvitanich et al. 1991). The bacterium is Gram- 
negative, nonmotile, aerobic, and develops within vacuoles of the host cell cytoplasm (Fryer et al. 1992). Although similar looking bacteria have been described from nonsalmonid fish species, none to date have been shown to cause piscirickettsiosis in salmonid fish (Fryer \& Mauel 1997).

The disease (piscirickettsiosis) caused by Piscirickettsia salmonis is characterized by a severe necrosis and inflammation of the liver, spleen, intestine, and haematopoietic tissues of the kidney (Larenas et al. 1995). Internal signs may include an enlargement of the kidney and spleen and a mottled to pustular appearance of the liver, the latter more prominent in chronic forms of the disease (Bravo \& Campos 1989, Cvitanich et al. 1991). Although coho salmon Oncorhynchus kisutch are the most susceptible host to $P$. salmonis, rainbow trout $O$. mykiss, chinook salmon O. tshawytscha, and Atlantic salmon Salmo salar are known to suffer from piscirickettsiosis in Chile (Garcés et al. 1991) and British Columbia, Canada (Evelyn et al. 1998). Strains of the bacterium have been associated with a chronic disease in net pen reared chinook and pink salmon $O$. gorbuscha in British Columbia (Evelyn 1992) and among Atlantic salmon in eastern Canada (Cusak et al. 1997, Jones et al. 1998), Norway (Olsen et al. 1997), Ireland (Rodger \& Drinan 1993) and Scotland (Grant et al. 1996).

A marine reservoir host for Piscirickettsia salmonis has been suspected, particularly in Chile, where the industry depended on the introduction of salmonids which are not native to the southern hemisphere (Donaldson \& Joyner 1983). It was only after the introduction of salmon into the seawater net pens that the disease became evident (Bravo \& Campos 1989). Although $P$. salmonis has been found associated with ova from infected females (Larenas et al. 1996) and occasionally among fish in freshwater (Gaggero et al. 1995), most salmon become infected only after entering seawater. Vertical transmission, if it occurs, is thought to be a rare event and there is no known vector for P. salmonis (Fryer \& Lannan 1996).

Intracellular rickettsia-like organisms have been detected among nonsalmonid fish in both sea- and freshwater, including European seabass Dicentrarchus labrax, fokaka Tetrodon fahaka, dragonet Callionymus lyra, tilapia Oreochromis niloticus, and blue-eyed plecostomus Panaque suttoni (Mohammed 1939, Davies 1986, Chen \& Chao 1994, Chen et al. 1994, Khoo et al. 1995, Comps et al. 1996). To date none of these rickettsia-like organisms from nonsalmonid fish have been well characterized or identified as Piscirickettsia salmonis nor have they been demonstrated to cause disease in salmonid fish.

White seabass Atractoscion nobilis have been spawned and mass reared at a private hatchery in southern
California since 1995. Experimental culture of white seabass has been ongoing since 1982, with the focus on restoring a popular sport and commercial fishery that has suffered serious declines (Vojkovich \& Reed 1983). In June 1998, significant mortality due to systemic infections with a rickettsia-like organism (RLO) occurred among certain groups of fish in the hatchery. This report describes 2 outbreaks, gross and microscopic pathology of the disease in infected fish and the isolation and partial characterization of the suspected causative agent.

\section{METHODS}

Fish. All of the fish examined during this study originated from a single hatchery supplied with pumped seawater from a local lagoon. Fish (50 to $75 \mathrm{~mm}$ ) from the original and a subsequent outbreak were collected from the hatchery. Moribund or dead fish or fish without external signs were examined during the outbreaks using standard necropsy procedures (Thoesen 1994). This included examinations for external parasites in skin and gill scrapings prior to the aseptic entry of the peritoneal cavity for preparing bacteriological cultures. Liver, kidney and spleen were analyzed for isolation of viruses, and the liver was studied for intracellular bacterial pathogens. In addition, routine bacterial cultures were attempted from the liver and kidney. Several organs were used as sources of routine bacterial cultures and for impression smears or placed into fixative for later microscopic examinations of stained tissue sections.

Light microscopy. Impression smears of the kidney, liver, and spleen were air dried, fixed in absolute methanol for $10 \mathrm{~min}$, and stained with Wright-Giemsa according to the method of Yasutake \& Wales (1983). Tissues for histological examination were fixed in Davidson's solution for $24 \mathrm{~h}$ and then transferred to $70 \%$ ethanol. Tissues were embedded in paraffin, sectioned at $5 \mu \mathrm{m}$, and stained with haematoxylin and eosin (Humason 1979).

Isolation and growth of the bacterium. Liver and kidney tissues from 6 moribund fish from the first outbreak were spread onto trypticase soy agar (TSA) supplemented with $0.45 \mu \mathrm{m}$ filtered $5 \%$ white seabass blood and incubated at $17^{\circ} \mathrm{C}$. In the second outbreak, we focused on isolation of the intracellular bacterium that was first observed in the initial outbreak. Livers known to contain the intracellular bacterium as demonstrated by stained tissue smears were aseptically removed and portions placed into minimal essential medium (MEM) without antibiotics and treated as described by Fryer et al. (1990) for isolation of Piscirickettsia salmonis. Two cell lines were inoculated, the 
salmonid cell line CHSE-214 (Lannan et al. 1984) and a recently established cell line from white seabass kidney (WSBK, authors' unpubl. data). Flasks $\left(25 \mathrm{~cm}^{2}\right)$ of CHSE-214 and WSBK cells were incubated at 15 and $20^{\circ} \mathrm{C}$ and observed daily for evidence of changes in the cell monolayer. Presence of the bacterium, hereafter referred to as the white seabass $P$. salmonis-like organism (WSPSLO) in the cell cultures was confirmed by subsequent subcultures on new CHSE-214 cells and by staining of infected CHSE-214 cells after fixation. Concentrations of the bacterium in cell cultures were estimated by $50 \%$ tissue culture infective dose $\left(\mathrm{TCID}_{50}\right)$ assays on CHSE-214 cells as described by Fryer et al. (1990) except that the cells were incubated at $20^{\circ} \mathrm{C}$ for $14 \mathrm{~d}$.

For virological analyses the kidney and spleen from the same fish were homogenized, centrifuged, and treated with antibiotics (Thoesen 1994) to provide inocula for CHSE-214 and WSBK cell lines at $20^{\circ} \mathrm{C}$. The cells were observed daily for $21 \mathrm{~d}$. No blind passages were attempted.

Stability of the bacterium. Conditions for the storage or stability of the WSPSLO were examined following incubations at $4,13,20,37$, and $56^{\circ} \mathrm{C}$, after a single freeze $\left(-20^{\circ} \mathrm{C}\right)$ and thaw cycle, after dehydration/rehydration, and after suspensions in seawater and distilled water. The WSPSLO was grown in CHSE-214 cells at $20^{\circ} \mathrm{C}$ and after $10 \mathrm{~d}$ the cell culture medium was harvested and the cell debris removed by centrifugation at $2500 \times g$ for $10 \mathrm{~min}$. The concentrations of WSPSLO infectious for CHSE-214 cells were evaluated after storage at 5 temperatures for a period from $1 \mathrm{~h}$ to $21 \mathrm{~d}$. The cell culture medium containing WSPSLO was divided into 35 tightly sealed vials such that 7 vials were at each of 5 temperatures $\left(4,13,20,37\right.$ and $\left.56^{\circ} \mathrm{C}\right)$. The concentrations of WSPSLO were evaluated by the $\mathrm{TCID}_{50}$ analysis from a vial removed from each temperature at 1 and $24 \mathrm{~h}$ and then at $3,7,14$, and $21 \mathrm{~d}$.

The effect of a freeze and thaw on the bacterium was evaluated by dividing cell culture medium containing the WSPSLO into 3 aliquots of $1 \mathrm{ml}$ each in closed vials. One vial was immediately evaluated for the concentration of WSPSLO by TCID 50 analysis on CHSE-214 cells. The second vial was placed at $4^{\circ} \mathrm{C}$ and the third vial frozen at $-20^{\circ} \mathrm{C}$. Both of these vials were held for $48 \mathrm{~h}$ and then removed to room temperature $\left(25^{\circ} \mathrm{C}\right)$. $\mathrm{TCID}_{50}$ analysis was used to evaluate the concentrations of the WSPSLO in the medium of previously frozen and the $4^{\circ} \mathrm{C}$ treated vials.

The effect of dehydration on the viability of the WSPSLO was evaluated by placing $100 \mu \mathrm{l}$ aliquots of the culture medium from infected CHSE-214 cells in either the wells of 24 -well plates or tightly sealed vials at $15^{\circ} \mathrm{C}$. After $3 \mathrm{~d}$, distilled water $(100 \mu \mathrm{l})$ was added to each well with desiccated WSPSLO supernatant; this was immediately diluted in MEM-2 for titration on CHSE-214 cells by TCID 50 analysis and was compared to the concentration of the WSPSLO present in the sealed vials.

To examine the stability of the WSPSLO in seawater, the bacteria were collected from the supernatant of a $10 \mathrm{~d}$ infected $25 \mathrm{~cm}^{2}$ flask of CHSE-214 cells by centrifugation at $10000 \times g$ for $10 \mathrm{~min}$. The cells were resuspended in $1 \mathrm{ml}$ of MEM- 0 and then diluted a further 1:10 in either MEM-2, full strength seawater (35 ppt), or distilled water. The concentrations of WSPSLO were evaluated by $\mathrm{TCID}_{50}$ analysis immediately after dilution into each media and again after $72 \mathrm{~h}$ at $10^{\circ} \mathrm{C}$.

Fluorescent antibody tests. The WSPSLO was partially purified from the cell culture medium of infected CHSE-214 cells by 2 cycles of centrifugation. An initial centrifugation of $2500 \times g$ for 10 min removed larger cell debris and a second centrifugation at $10000 \times g$ for 10 min concentrated the bacterial cells into a pellet. The pellet was resuspended in phosphate buffered saline (PBS). This preparation, which contained approximately $2 \mathrm{mg}$ total protein, was injected into a New Zealand white rabbit over a series of 3 injections. The first subcutaneous injection contained $1 \mathrm{mg}$ protein suspended in Freund's complete adjuvant. The 2 booster injections containing $0.5 \mathrm{mg}$ protein each and were administered with Freund's incomplete adjuvant 4 and 6 wk after the initial injection. Blood was collected $10 \mathrm{~d}$ following the last injection and the serum was separated and stored at $-20^{\circ} \mathrm{C}$. The anti WSPSLO serum was used in indirect fluorescent antibody tests (IFAT) as described for Piscirickettsia salmonis by Lannan et al. (1991). Anti-P. salmonis rabbit serum was provided by J. L. Fryer (Oregon State University, Corvallis). Slides containing fixed $P$. salmonis from infected coho salmon or infected CHSE-214 cells and WSPSLO from infected CHSE-214 cells were compared in reciprocal IFAT with the 2 rabbit sera according to Lannan et al. (1991).

Virulence for salmonid fish. Upon isolation of the WSPSLO there were no groups of white seabass available that were not potentially exposed to the agent. The virulence of the newly isolated bacterium, however, was evaluated in juvenile coho salmon $(10 \mathrm{~g})$ by intraperitoneal injection. Ten coho salmon were injected with $10^{2.5}$ TCID $_{50}$ WSPSLO fish ${ }^{-1}$ with the culture medium from a $10 \mathrm{~d}$ infected flask of CHSE-214 cells. A control group of 10 fish received only MEM from uninfected CHSE-214 cells. The fish were held in individual $130 \mathrm{l}$ aquaria receiving $15^{\circ} \mathrm{C}$ well water at $3.81 \mathrm{~min}^{-1}$. Fish were fed a commercial ration at $2 \%$ body weight $\mathrm{d}^{-1}$. Dead or severely moribund fish were removed and subjected to standard necrospy procedures, including impression smears of the kidney and liver and isolation of the bacterium from the kidney 
using CHSE-214 cells as previously described. Tissues were also collected from moribund fish for microscopic examinations of stained tissue sections. At the end of the study $(14 \mathrm{~d})$ the remaining fish in the injected group and all of the control fish were euthanized and examined for presence of the bacterium in stained impression smears of the kidney and liver and isolation on CHSE-214 cells.

\section{RESULTS}

\section{Field observations}

The presence of the WSPSLO as associated with 2 episodes of mortality among juvenile white seabass in the hatchery was examined. In the first examination, $59 \mathrm{~d}$ old white seabass (average length $50 \mathrm{~mm}$ ) were thin, with pale gills, and the daily mortality rate was $4 \%$. The seawater supplying the hatchery was $21.0^{\circ} \mathrm{C}$ and salinity was 34.0 parts per thousand (ppt). Of the 6 fish examined on this date, 1 had an opaque cornea and all 6 fish had pale white foci in the liver (Fig. 1). Vacuolation in the retina and hind brain of 1 fish in this group suggested a concurrent infection with viral nervous necrosis virus (VNNV) and characteristic nodavirus virions were subsequently observed by electron microscopy (data not shown). The mortality rate increased over the next $9 \mathrm{~d}$ in this rearing unit, and at the end of this period the remaining fish were destroyed. Weekly monitoring of different lots of fish at the hatchery began at this time.

A second episode of mortality occurred approximately 5 to 6 wk after the initial outbreak among 2 groups of 90 and $76 \mathrm{~d}$ old white seabass. The external signs of affected fish were similar to those in the first outbreak. Among 6 moribund fish from each group, liver lesions (pale white foci) were detected in all fish. The water temperature was 20.4 to $20.6^{\circ} \mathrm{C}$ and the salinity $30.4 \mathrm{ppt}$. Of the 30 fish showing no external

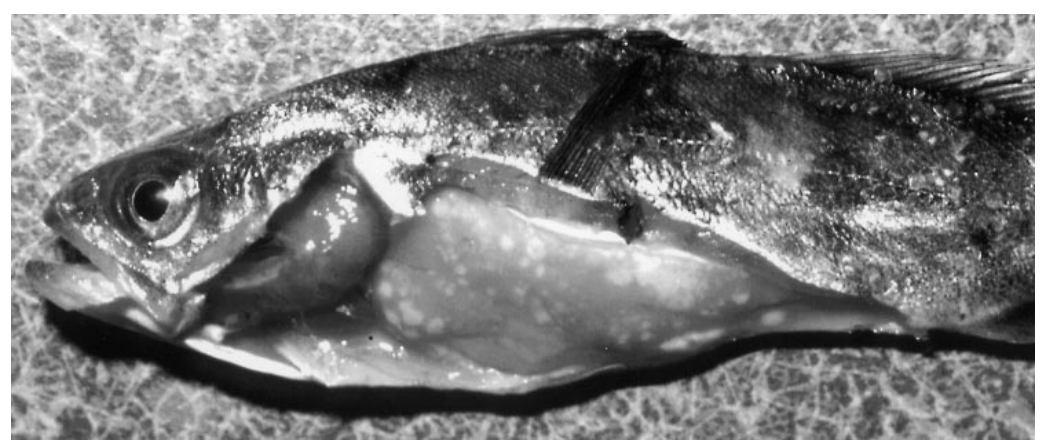

Fig. 1. Atractoscion nobilis. A juvenile white seabass (65 $\mathrm{mm}$ in total length) with liver lesions associated with infections with a rickettsia-like organism (WSPSLO) signs of infection from each group, 2 fish had pale white foci in the liver. The livers from these 2 fish from each age group that showed focal lesions were used for isolation of the WSPSLO. The daily mortality rate increased to $3-4 \%$, and these groups of fish were subsequently destroyed. Both of these groups had been in the hatchery building at the same time as those fish in the initial outbreak. No VNNV was observed in either of these groups. Examinations of gill and skin scrapings failed to demonstrate a consistent parasite or external bacterium among groups of moribund fish from either outbreak.

\section{Isolation and growth of the bacterium}

TSA cultures of liver and kidney were positive from 2 of 6 white seabass from the first examination. Small colonies from the livers of both positive fish were Gram-negative nonmotile cocci identified as Acinetobacter sp. The kidney from 1 of these 2 fish yielded colonies of Vibrio alginolyticus and V. parahemolyticus. Smears from the liver foci (Fig. 1) of all 6 fish had basophilic cocci or coccobacilli, 1.0 to $1.2 \mu \mathrm{m}$, that were usually intracellular and often in pairs. These organisms were intracellular, Gram-negative, and of a size and shape consistent with Piscirickettsia salmonis (Fig. 2A). Intracellular bacteria were again observed among both groups of fish in the second examination.

The intracellular bacterium was isolated from all of the 4 fish examined from the second outbreak in both the CHSE-214 and WSBK cell lines (Fig. 2B). Cells in the monolayer first became rounded $2 \mathrm{~d}$ after inoculation of either cell line, and monolayer changes progressed to open plaques 3 to $5 \mathrm{~d}$ after inoculation at $20^{\circ} \mathrm{C}$ (Fig. 2B). Cytopathic effects appeared approximately $1 \mathrm{~d}$ earlier at $20^{\circ} \mathrm{C}$ than at $15^{\circ} \mathrm{C}$. Presence of the bacterium in the cell cultures was confirmed by staining monolayers of the inoculated CHSE-214 and WSBK cells (Fig. 2C,D). Intracellular bacteria were detected both within and outside of cytoplasmic vacuoles of infected cells. No bacteria were present among control cells that were not inoculated with white seabass extracts. The coccoidshaped bacterial cells ranged from 0.5 to $1.0 \mu \mathrm{m}$ in diameter, appearing singly or in pairs. Based on the appearance of characteristic cytopathic effects in CHSE-214 cells concentrations of the WSPSLO reached $10^{6} \mathrm{TCID}_{50} \mathrm{ml}^{-1}$ at both temperatures but more quickly at $20^{\circ} \mathrm{C}$.

There was no evidence of cytopathic effects in CHSE-214 or WSBK cells 
Fig. 2. White seabass rickettsia-like organism (WSPSLO). (A) Atractoscion nobilis. Kidney imprint from an infected juvenile white seabass showing a large group of bacterial cells in the cytoplasm of an infected cell. Lieshman-Giemsa stain. Scale bar $=25 \mu \mathrm{m}$. (B) CHSE214 cells at $20^{\circ} \mathrm{C} 3 \mathrm{~d}$ after inoculation with a homogenate from the kidney of infected white seabass. The focal cytopathic effect and detachment of the cells from the substrate are evident. Phase contrast. Scale bar $=100 \mu \mathrm{m}$. (C) Uninfected CHSE-214 control cells and (D) CHSE-214 cells infected with WSPSLO after $7 \mathrm{~d}$ at $20^{\circ} \mathrm{C}$. Bacteria are evident within and outside of cytoplasmic vacuoles. Stains for (C) and (D) were Wright-Giemsa. Scale bars $=20 \mu \mathrm{m}$

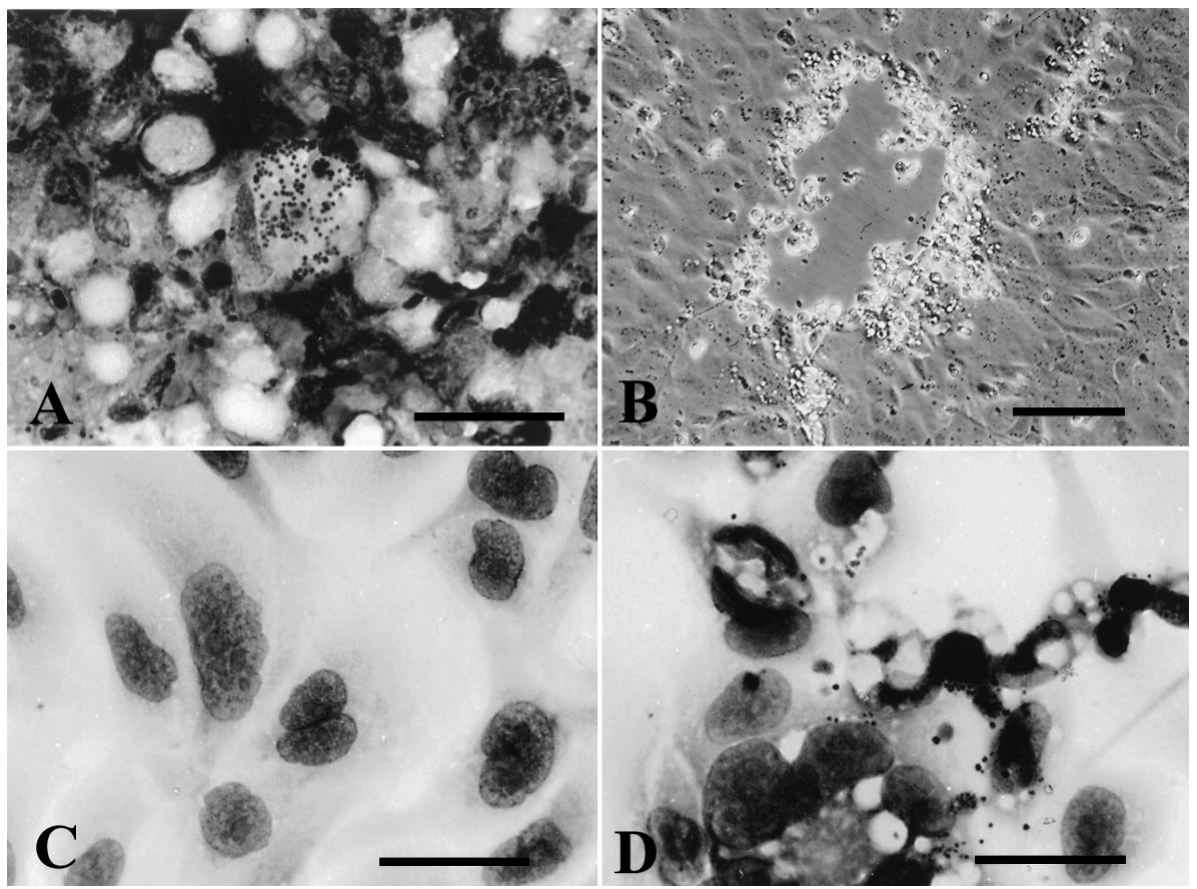

inoculated with liver, kidney, and spleen extracts from affected white seabass that were treated with antibiotics. This suggested a viral agent capable of replicating in these cell lines was not present.

\section{Stability of the bacterium}

The WSPSLO was relatively stable at storage temperatures of 4 and $13^{\circ} \mathrm{C}$ over $14 \mathrm{~d}$ (Table 1). However, after $7 \mathrm{~d}$ at $20^{\circ} \mathrm{C}$ the WSPSLO lost infectivity. Temperatures of 37 and $56^{\circ} \mathrm{C}$ eliminated infectivity within 1 to $24 \mathrm{~h}$. Infectivity of the WSPSLO was reduced approximately 100 -fold by a single freeze/thaw cycle. The initial concentration of the bacterium was $10^{4.9} \mathrm{TCID}_{50} \mathrm{ml}^{-1}$. After $48 \mathrm{~h}$ at $4^{\circ} \mathrm{C}$, the concentration was $10^{4.3} \mathrm{TCID}_{50} \mathrm{ml}^{-1}$; after $48 \mathrm{~h}$ at $-20^{\circ} \mathrm{C}$ and thawing, the bacterial concentration was reduced to $10^{2.8} \mathrm{TCID}_{50} \mathrm{ml}^{-1}$

WSPSLO preparations subjected to dehydration were not infective for CHSE-214 cells. In contrast, WSPSLO preparations maintained at the same temperature in tightly sealed vials retained an infectivity of $10^{5.7} \mathrm{TCID}_{50} \mathrm{ml}^{-1}$.

The WSPSLO was stable in seawater. Concentrations of the bacterium immediately after dilution into MEM, distilled water, or seawater were $10^{6.4}, 10^{3.3}$, and $10^{6.5} \mathrm{TCID}_{50} \mathrm{ml}^{-1}$, respectively. After $72 \mathrm{~h}$, the concentrations of WSPSLO were $10^{6.0}$, undetectable, and $10^{6.1}$ TCID $_{50} \mathrm{ml}^{-1}$ for the MEM, distilled water, and seawater, respectively.

\section{Fluorescent antibody microscopy}

The rabbits injected with WSPSLO produced a strong antibody response detected by specific fluorescence of bacterial cells in the infected CHSE-214 cultures. A similar response was obtained with the antiPiscirickettsia salmonis rabbit serum on fixed coho salmon tissues or CHSE-214 cells infected with $P$. salmonis. In both tests, bacteria stained positive at serum dilutions up to 1:2000-1:5000. Differences in the reactivity of the 2 antisera were obtained in the reciprocal IFAT. The anti-WSPSLO serum reacted positively with $P$. salmonis but only at dilutions up to 1:100 and not beyond. Similarly, anti-P. salmonis serum reacted positively with the WSPSLO at serum dilutions of 1:50-1:100 but not at greater dilutions.

\section{Microscopic pathology}

Infection with the WSPSLO was associated with microscopic lesions in the skin and multiple internal organs of white seabass (Fig. 3). Cutaneous lesions were characterized by large focal areas of granulomatous inflammation in the integument and underlying musculature (Fig. 3A). Hepatic lesions were prominent (Fig. 3B) and consisted of large focal regions of coagulative necrosis of the parenchyma (Fig. 3C). Granulocytes and histocytes were scattered among the remains of degenerating hepatocytes. Affected hepatocytes had lost normal cell-to-cell adhesions and their nuclei 
Table 1. Concentrations $\left(\mathrm{TCID}_{50} \mathrm{ml}^{-1}\right.$ ) of the white seabass rickettsia-like organism infectious for the CHSE-214 cell line as determined after incubation (storage) at 5 temperatures over a $21 \mathrm{~d}$ period. nd: no infectivity detected

\begin{tabular}{|lccccc|}
\hline \multirow{2}{*}{ Time } & \multicolumn{5}{c|}{ Storage temperature $\left({ }^{\circ} \mathrm{C}\right)$} \\
& 4 & 13 & 20 & 37 & 56 \\
\hline $0 \mathrm{~h}$ & $10^{5.9}$ & & & & \\
$1 \mathrm{~h}$ & $10^{5.7}$ & $10^{5.9}$ & $10^{5.8}$ & $10^{2.4}$ & nd \\
$24 \mathrm{~h}$ & $10^{5.5}$ & $10^{5.8}$ & $10^{5.6}$ & nd & nd \\
$3 \mathrm{~d}$ & $10^{5.1}$ & $10^{5.3}$ & $10^{4.1}$ & nd & nd \\
$7 \mathrm{~d}$ & $10^{5.0}$ & $10^{4.8}$ & $10^{1.8}$ & nd & nd \\
$14 \mathrm{~d}$ & $10^{5.7}$ & $10^{3.2}$ & nd & nd & nd \\
$21 \mathrm{~d}$ & $10^{1.8}$ & nd & nd & nd & nd \\
& & & & & \\
\hline
\end{tabular}

were pyknotic and/or karyorrhectic. Necrosis and granulomatous inflammation were also prominent in the mesenteric fat (Fig. 3D) and the spleen. The anterior kidney contained multiple granulomatous foci (Fig. 3E). Numerous basophilic coccoid bodies filled the cytoplasm of cells at the center of these liver and kidney lesions (Fig. 3E). The size, shape, and location of these bodies were consistent with the WSPSLO. Also, several other organs had prominent foci of necrosis: exocrine pancreas, retina, brain stem and meninges, and the lamina propria of the small and large intestine (not shown). In the one fish with vacuolation in the retina and brain stem the presence of VNNV-like virions was confirmed by electron microscopy.

\section{Virulence for salmonid fish}

Eight of the 10 coho salmon injected with the WSPSLO died or were severely moribund within $10 \mathrm{~d}$. Dead fish had few external signs. Internally, signs were consistent with a haemorrhagic septiceamia. The gills were pale. Haemorrhage and congestion were prominent throughout the visceral fat surrounding the intestinal ceca; the large intestine was filled with blood, and the muscle surrounding the peritoneal
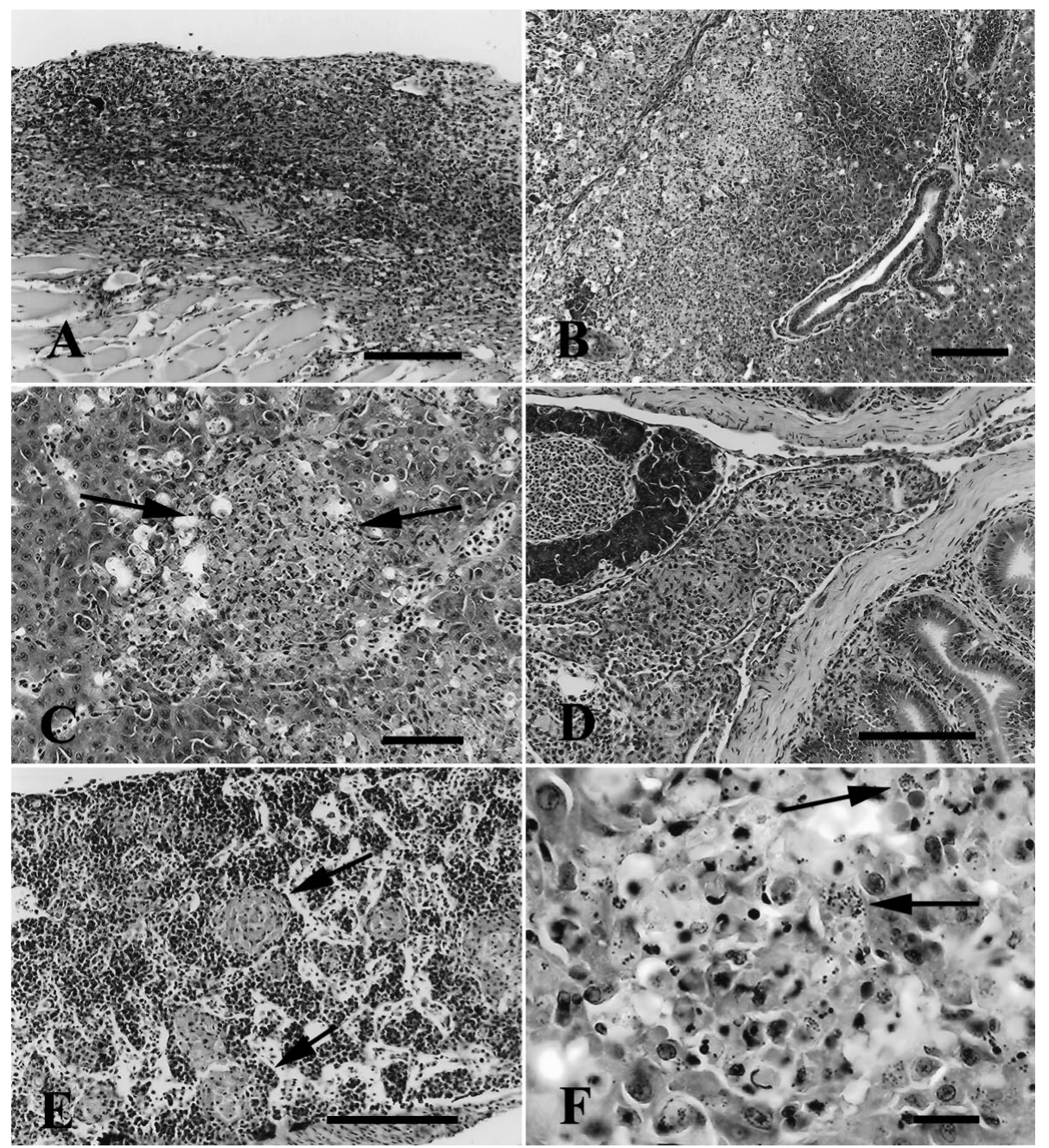

Fig. 3. Atractoscion nobilis. Microscopic lesions in H\&E stained tissue sections from white seabass infected with the white seabass rickettsia-like organism. (A) Granulomatous inflammation of the epidermis, dermis, and epaxial musculature. Scale bar $=$ $100 \mu \mathrm{m}$. (B) Focal hepatic lesions characterized by necrosis and infiltration with mononuclear cells. Scale bar $=100 \mu \mathrm{m}$. (C) A foci of necrosis in the liver. Affected hepatocytes have lost cell-cell adhesions and demonstrate pyknotic and karyorrhectic nuclei and form a focus (arrows) surrounded by normal hepatocytes. Scale bar $=25 \mu \mathrm{m}$. (D) Granulomatous inflammation and necrosis of the parenchyma of the spleen adjacent to the small intestine. Scale bar $=100 \mu \mathrm{m}$. (E) Multiple and focal aggregates of macrophages (arrows) in the interstitium of the anterior kidney. Scale bar $=100 \mu \mathrm{m}$. (F) Groups of bacteria in the cytoplasm of hepatocytes (arrows). Scale bar $=25 \mu \mathrm{m}$ 
cavity displayed scattered petechial haemorrhage. Gross lesions on the liver were limited to multiple, small, pale white foci, usually less than $1 \mathrm{~mm}$ in diameter. Microscopically, these discolored foci corresponded to multifocal hepatic necrosis associated with the WSPSLO.

Kidney imprints from all exposed coho salmon had characteristic intracellular bacterial cells, including the 2 fish that survived $14 \mathrm{~d}$ after injection. The WSPSLO was recovered on CHSE-214 cells from all fish injected with the bacterium that were examined. This included 2 freshly dead fish, 2 severely moribund fish and the 2 live fish at the termination of the study. The remaining fish injected with the bacterium that died were deemed too autolyzed for isolation attempts and only stained smears were collected from these fish, all of which had abundant intracellular WSPSLO. Control coho salmon examined at the termination of the study were all negative for WSPSLO.

\section{DISCUSSION}

Piscirickettsiosis is considered the most serious bacterial disease affecting the salmon industry in Chile (Lannan \& Fryer 1993, Almendras \& Fuentealba 1997, Lannan et al. 1999) and has caused significant mortality among pen-reared salmon in Canada, Norway, Scotland and Ireland (Brockelbank et al. 1992, Rodger \& Drinan 1993, Cusak et al. 1997, Jones et al. 1998). Rickettsia-like agents have also been found among several nonsalmonid fish (Davies 1986, Chen \& Chao 1994, Chen et al. 1994, Khoo et al. 1995, Comps et al. 1996) but none have been shown to induce piscirickettsiosis in salmonid fish. From our initial investigations of a Piscirickettsia salmonis-like agent (WSPSLO) among cultured white seabass, we conclude that this bacterium causes a disease very similar to piscirickettsiosis in white seabass and in salmonid fish experimentally infected with the bacterium.

Piscirickettsia salmonis causes mortality among coho salmon in Chile that may reach $90 \%$ (Bravo \& Campos 1989), but infected Atlantic salmon from Canada, Norway, and Ireland generally suffer lesser mortality of 0.06 to $15 \%$ (Brocklebank et al. 1992, Evelyn 1992, Olsen et al. 1993, Rodger \& Drinan 1993, Jones et al. 1998). The mortality among groups of white seabass in the 2 outbreaks reached $4 \% \mathrm{~d}^{-1}$ and no cumulative mortality could be calculated since the groups were destroyed. Mortality presumed due to the WSPSLO among white seabass in the hatchery occurred at water temperatures of 20 to $21^{\circ} \mathrm{C}$, a temperature good for in vitro growth. In contrast, temperatures of 20 to $21^{\circ} \mathrm{C}$ have been shown to retard the growth of $P$. salmonis in vitro (Fryer et al. 1990) and most epizootics in Pacific and Atlantic salmon occur at water temperatures of 9 to $16^{\circ} \mathrm{C}$ (Cvitanich et al. 1991).

External signs among white seabass suffering from WSPSLO infections are similar to those of coho salmon with naturally acquired infections with Piscirickettsia salmonis in Chile (Branson \& Nieto-Diaz-Munoz 1991, Lannan \& Fryer 1993). Similarities include lethargy, anemia and skin lesions. Epidermal lesions when present in white seabass were characterized more by patchy areas of hyperplasia than haemorrhage and ulceration, as reported for coho salmon. Enlargement of the kidney and spleen in white seabass was similar to that reported for infected coho salmon (Branson \& Nieto-Diaz-Munoz 1991). The most pronounced internal sign of infection in certain groups of white seabass however, were the white foci of necrosis and inflammation in the liver, a feature of the more chronic form of piscirickettsiosis in coho salmon (Bravo \& Campos 1989).

Smears made directly from similar lesions in the kidney and spleen of infected white seabass contained numerous intracellular, Gram-negative coccobacilli. Estimates to determine the concentrations of WSPSLO per gram of infected white seabass tissue were not attempted; however, evidence that they were abundant includes the large number of intracellular organisms in stained smears and tissue sections and the appearance of cytopathic effect (CPE) within $2 \mathrm{~d}$ post inoculation of fish cell lines. The WSPSLO could be readily isolated from infected fish tissues (liver) and several cell lines from salmonid and cyprinid (epithelioma papillosum cyprini [EPC]) supported growth of the organism (authors' unpubl. data). Curiously, there was no apparent advantage of using the WSBK line of host origin for the isolation or growth of the WSPSLO. This lack of cell specificity has also been reported for Piscirickettsia salmonis (Fryer et al. 1990, Almendras et al. 1997). In contrast to P. salmonis, which prefers temperatures from 15 to $18^{\circ} \mathrm{C}$ and shows slower growth at $20^{\circ} \mathrm{C}$ (Fryer et al. 1990), CHSE-214 cells inoculated with the tissues containing the WSPSLO developed $\mathrm{CPE}$ more rapidly at $20^{\circ} \mathrm{C}$ than at $15^{\circ} \mathrm{C}$.

The stability of the WSPSLO is nearly identical to that reported for Piscirickettsia salmonis by Lannan \& Fryer (1994), including a 100-fold reduction in infectivity following a single freeze/thaw cycle and total loss of infectivity in distilled water. Improved survival at lower temperatures and in seawater are features in common to both bacteria (Lannan \& Fryer 1994). Although not attempted with P. salmonis, we presume it would survive poorly as did the WSPSLO upon dehydration/rehydration.

The gross and microscopic pathology and initial properties of the bacteria involved in the white seabass outbreaks we investigated were quite similar to those 
known for Piscirickettsia salmonis in Pacific salmon. Although subtle differences in the temperature for isolation and growth of the respective bacteria were noted, the similarities would suggest that the organisms in the 2 fish hosts are closely related. With warm water events (El Niño) there have been some overlapping of the distribution of white seabass with anadromous salmonid populations in California. To date, however, no North American salmonid populations south of the Canadian border are known to be infected with $P$. salmonis. Evidence that the 2 bacteria differ, however, was demonstrated by the reciprocal antigenic analyses by IFAT. P. salmonis is considered an 'Other Significant Disease' by the Office of International des Epizooties (1997) and the IFAT is used as a confirmatory test. Given this criteria, and the nonsalmonid host involved, it is unresolved as to whether the seabass isolate should be considered $P$. salmonis for regulatory purposes.

Unfortunately, white seabass free of exposures to the WSPSLO were not available for laboratory testing. However, the virulence of the WSPSLO was clearly demonstrated by the severe systemic disease suffered by juvenile coho salmon receiving intraperitoneal injections of the bacterium from infected CHSE-214 cells. The concentrations of bacteria received by the coho salmon in our study were below those determined to be the $50 \%$ lethal dose calculated for LF-89 $\left(10^{3.0}\right.$ $\left.\mathrm{TCID}_{50}\right)$, the most virulent strain of Piscirickettsia salmonis (Smith et al. 1996, House et al. 1999). Because water temperatures and sizes of the fish varied slightly between the different studies, we cannot compare the data statistically but the WSPSLO was clearly highly pathogenic to juvenile coho salmon. The recovery of the WSPSLO from dead coho salmon on CHSE-214 cells and the abundant intracellular organisms in tissue smears from infected fish demonstrate that the organism causing the mortality among coho salmon was the bacterium as originally isolated from white seabass. The susceptibility of juvenile white seabass to the WSPSLO has not yet been examined, and we cannot conclusively state that this organism is the cause of the disease until Koch's postulates are completed. However, data from the hatchery outbreaks and subsequent examinations of the same disease and intracellular bacterium among white seabass originating from the hatchery that were subsequently held in seawater net pens (authors' unpubl. data) implicate the WSPSLO as a cause of the disease and mortality. Experimental exposures of white seabass are planned in future studies to confirm this hypothesis.

The source and reservoir hosts for the WSPSLO remains unclear. Since the hatchery uses unfiltered seawater drawn from the local lagoon, any of many resident species, including white seabass, might be im- plicated. In the Pacific Ocean Piscirickettsia salmonis has only been identified in salmon in British Columbia and the southern region of Chile (Fryer \& Mauel 1997). These 2 locations are quite distant from each other and from the location in southern California, where white seabass were found infected with the WSPSLO. There is, however, an overlap between the migration of white seabass adults, which have been recorded as far north as Juneau, Alaska (Emmett et al. 1991), and coho salmon which can range as far south as Baja California (Hart 1986, Hart \& Dell 1986). Whether the bacterium could have been transmitted between these species during these overlapping migrations remains conjectural. A perhaps more reasonable source for the bacterium among cultured white seabass is a local reservoir among resident populations of marine fish inhabiting the lagoon from which the water supplying the white seabass hatchery is obtained. We plan to examine samples from fish in the lagoon by the polymerase chain reaction assay as developed for $P$. salmonis (Mauel et al. 1996) but with the modifications required to detect the WSPSLO. In addition, we plan a more extensive characterization of the WSPSLO which will include sequencing of ribosomal genes and identification of major proteins recognized by rabbit antiWSPSLO and anti-P. salmonis sera (Kuzyk et al. 1996, Barnes et al. 1998, Mauel et al. 1999).

In conclusion, we present data that a Piscirickettsia salmonis-like organism (WSPSLO) as found in a marine nonsalmonid fish (white seabass) is associated with a significant disease in the host of origin and upon experimental infection results in high mortality among coho salmon. Small differences in optimal growth temperature in vitro and antigens recognized by rabbit antisera exist between the WSPSLO and P. salmonis. However, the many similarities between the 2 bacteria suggest to us that white seabass, and perhaps several other marine fish species, can act as hosts and reservoirs for $P$. salmonis or $P$. salmonis-like organisms that may then infect and cause disease in net pen reared salmon.

Acknowledgements. This work was supported in part by funds provided by the California Department of Fish and Game through the Ocean Resource Hatchery Enhancement Project. We appreciated the assistance of personnel from the Hubbs Research Institute, Carlsbad, California, USA.

\section{LITERATURE CITED}

Almendras FE, Fuentealba IC (1997) Salmonid rickettsial septicemia caused by Piscirickettsia salmonis: a review. Dis Aquat Org 29:137-144

Almendras FE, Jones SRM, Fuentealba C, Wright GM (1997) In vitro infection of a cell line from Ictalurus nebulosus with Piscirickettsia salmonis. Can J Vet Res 61:66-68 
Barnes MN, Landolt ML, Powell DB, Winton JR (1998) Purification of Piscirickettsia salmonis and partial characterization of antigens. Dis Aquat Org 33:33-41

Branson EJ, Nieto-Diaz-Munoz D (1991) Description of a new disease condition occurring in farmed coho salmon, Oncorhynchus kisutch (Walbaum), in South America. J Fish Dis 14:147-156

Bravo S, Campos M (1989) Coho salmon syndrome in Chile. Am Fish Soc Fish Health Sect Newsl 17:3

Brocklebank JR, Speare DJ, Armstrong RD, Evelyn T (1992) Septicemia suspected to be caused by a rickettsia-like agent in farmed Atlantic salmon. Can Vet J 33:407-408

Chen RS, Chao CB (1994) Outbreaks of a disease caused by a rickettsia-like organism in cultured tilapias in Taiwan. Fish Pathol 29(2):61-71

Chen SC, Tung MC, Chen SP, Tsai JF, Wang PC, Chen RS, Lin SC, Adams A (1994) Systemic granulomas caused by a rickettsia-like organism in Nile tilapia, Oreochromis niloticus (L.), from southern Taiwan. J Fish Dis 17:591-599

Comps M, Raymond MJ, Plassiart GN (1996) Rickettsia-like organism infecting juvenile sea-bass Dicentrarchus labrax. Bull Eur Assoc Fish Pathol 16:30-33

Cusak R, Groman D, Jones S (1997) The first reported rickettsial infection of Atlantic salmon in Eastern North America. In: 8th International Conference: Diseases of Fish and Shellfish. European Association of Fish Pathologists, Heriot-Watt University, Edinburgh, September 1997, p 1-109

Cvitanich JD, Garate NO, Smith CE (1991) The isolation of a rickettsia-like organism causing disease and mortality in Chilean salmonids and its confirmation by Koch's postulate. J Fish Dis 14:121-145

Davies AJ (1986) A rickettsia-like organism from dragonets, Callionymus lyra L. (Teleosti: Callionymidae) in Wales. Bull Eur Assoc Fish Pathol 6:103

Donaldson LR, Joyner T (1983) The salmonid fishes as a natural livestock. Sci Am 249:51-63

Emmett RL, Stone SL, Hinton SA, Monaco EC (1991) Distribution and abundance of fishes and invertebrates in west coast estuaries, Vol II: species life history summaries. ELMR Rep No. 8. NOAA/NOS Strategic Environmental Asessments Division, Rockville, MD

Evelyn TPT (1992) Salmonid rickettsial septicemia. In: Kent ML (ed) Diseases of seawater netpen-reared salmonid fishes in the Pacific northwest. Can Spec Pub Fish Aquat Sci 116, Dept Fisheries and Oceans, Nanaimo, BC, p 18-19

Evelyn TPT, Kent ML, Poppe TT, Bustos P (1998) Bacterial diseases. In: Kent ML, Poppe TT (eds) Diseases of seawater netpen-reared salmonid fishes. Quadra Printers Ltd, Nanaimo, BC, p 31-34

Fryer JL, Lannan CN (1996) Rickettsial infections of fish. Annu Rev Fish Dis 6:3-13

Fryer JL, Mauel MJ (1997) The rickettsia: an emerging group of pathogens in fish. Emerg Infect Dis 3:137-144

Fryer JL, Lannan CN, Garcès LH, Larenas JJ, Smith PA (1990) Isolation of a rickettsia-like organism from diseased coho salmon Oncorhynchus kisutch in Chile. Fish Pathol 25: 107-114

Fryer JL, Lannan CN, Giovannoni SJ, Wood ND (1992) Piscirickettsia salmonis gen. nov., sp. nov., the causative agent of an epizootic disease in salmonid fishes. Int J Syst Bacteriol 42:120-126

Gaggero A, Castro H, Sandino AM (1995) First isolation of Piscirickettsia salmonis from coho salmon, Oncorhynchus kisutch (Walbaum), and rainbow trout, Oncorhynchus mykiss (Walbaum), during the freshwater stage of their life cycle. J Fish Dis 18:277-279
Garcés LH, Larenas JJ, Smith PA, Sandino S, Lannan CN, Fryer JL (1991) Infectivity of a rickettsia isolated from coho salmon (Oncorhynchus kisutch). Dis Aquat Org 11:93-97

Grant AN, Brown AG, Cox DI, Birkbeck TH, Griffen AA (1996) Rickettsia-like organism in farmed salmon. Vet Rec 138:423

Hart AC, Dell MB (1986) Early oceanic migrations and growth of juvenile Pacific salmon and steelhead trout. Int North Pac Fish Comm Bull 46

Hart JL (1986) Pacific fishes of Canada. Fish Res Board Can Bull 180

House ML, Bartholomew JL, Winton JR, Fryer JL (1999) Relative virulence of three isolates of Piscrickettsia salmonis for coho salmon Oncorhynchus kisutch. Dis Aquat Org 35: 107-113

Humason GL (1979) Animal tissue techniques. Freeman, San Francisco

Jones SRM, Markham RJF, Groman DB, Cusack RR (1998) Virulence and antigenic characteristics of a cultured Rickettsiales-like organism isolated from farmed Atlantic salmon Salmo salar in eastern Canada. Dis Aquat Org 33: 25-31

Khoo L, Dennis PM, Lewbart GA (1995) Rickettsia-like organisms in the blue-eyed plecostomus, Panaque suttoni (Eigenmann \& Eigenmann). J Fish Dis 18:157-164

Kuzyk MA, Thornton JC, Kay WW (1996) Antigenic characterization of the salmonid pathogen Piscirickettsia salmonis. Infect Immun 64(12):5205-5210

Lannan CN, Fryer JL (1993) Piscirickettsia salmonis, a major pathogen of salmonid fish in Chile. Fish Res 17:115-121

Lannan CN, Fryer JL (1994) Extracellular survival of Piscirickettsia salmonis. J Fish Dis 17:545-548

Lannan CN, Winton JR, Fryer JL (1984) Fish cell lines: establishment and characterization of nine cell lines from salmonids. In Vitro 20:671-676

Lannan CN, Ewing SA, Fryer JL (1991) A fluorescent antibody test for detection of the rickettsia causing disease in Chilean salmonids. J Aquat Anim Health 3:229-234

Lannan CN, Bartholomew JL, Fryer JL (1999) Rickettsial and chlamydial infections in fish. In: Woo PTK, Bruno DW (eds) Fish diseases and disorders, Vol 3, Viral bacterial and fungal infections. CAB International, Cambridge, p 245-267

Larenas J, Hidalgo VL, Garcés H, Fryer JL, Smith P (1995) Piscirickettsiosis: lesiones en salmón del Atlántico (Salmo salar) infectados naturalmente con Piscirickettsia salmonis. Avances Cienc Vet 10(1):53-58 (in Spanish with English abstract)

Larenas J, Astorga C, Contreras J, Smith P (1996) Detección de Piscirickettsia salmonis en ovas fertilizadas provenientes de trucha arco iris (Oncorhynchus mykiss) experimentalmente infectadas. (Piscirickettsia salmonis in ova obtained from rainbow trout (Oncorhynchus mykiss) experimentally inoculated). Arch Med Vet 28:161-166

Mauel MJ, Giovannoni SJ, Fryer JL (1996) Development of polymerase chain reaction assays for detection, identification, and differentiation of Piscirickettsia salmonis. Dis Aquat Org 26:189-195

Mauel MJ, Giovannoni SJ, Fryer JL (1999) Phylogenetic analysis of Piscirickettsia salmonis by $16 \mathrm{~S}$, internal transcribed spacer (ITS) and 23S ribosomal DNA sequencing. Dis Aquat Org 35:115-123

Mohammed Z (1939) The discovery of a rickettsia in a fish. Min Agric Cairo Tec Sci Serv Vet Sect Bull 214

Office International des Epizooties (1997) Diagnostic manual for aquatic animal diseases. OIE, Paris, p 161-168

Olsen AB, Melby HP, Speilberg L, Evensen O, Hastein T 
(1997) Piscirickettsia salmonis infection in Atlantic salmon Salmo salar in Norway-epidemiological, pathological and microbiological findings. Dis Aquat Org 31:35-48

Rodger HD, Drinan EM (1993) Observation of a rickettsia-like organism in Atlantic salmon, Salmo salar L., in Ireland. J Fish Dis 16:361-369

Smith PA, Contreras JR, Garcés LH, Larenas JJ, Oyanedel S, Caswell-Reno P, Fryer JL (1996) Experimental challenge of coho salmon and rainbow trout with Piscirickettsia salmonis. J Aquat Anim Health 8:130-134

Editorial responsibility: David Bruno, Aberdeen, United Kingdom
Thoesen JC (1994) Suggested procedures for the detection and identification of certain finfish and shellfish pathogens, 4th edn. American Fisheries Society, Fish Health Section, Bethesda, MD

Vojkovich M, Reed RJ (1983) White seabass Atractoscion nobilis in California-Mexico waters: status of the fishery. Rep Calif Coop Ocean Fish Invest 24:79-83

Yasutake WT, Wales JH (1983) Microscopic anatomy of salmonids: an atlas. Fish and Wildlife Service Resource Publication 150, Washington, DC

Submitted: March 31, 2000; Accepted: July 25, 2000

Proofs received from author(s): October 25, 2000 